\title{
Oral administration of chestnut tannins to reduce the duration of neonatal calf diarrhea
}

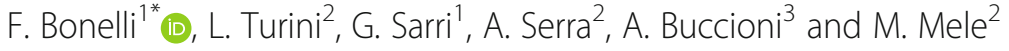

\begin{abstract}
Background: Neonatal calf diarrhea is generally caused by infectious agents and is a very common disease in bovine practice, leading to substantial economic losses. Tannins are known for their astringent and antiinflammatory properties in the gastro-enteric tract. The aim of this study was to evaluate the effect of the oral administration of chestnut tannins (Castanea sativa Mill.) in order to reduce the duration of calf neonatal diarrhea. Twenty-four Italian Friesian calves affected by neonatal diarrhea were included. The duration of the diarrheic episode (DDE) was recorded and the animals were divided into a control group (C), which received Effydral ${ }^{\circledR}$ in 2 I of warm water, and a tannin-treated group $(T)$, which received Effydral ${ }^{\oplus}$ in 2 I of warm water plus $10 \mathrm{~g}$ of extract of chestnut tannins powder. A Mann-Whitney test was performed to verify differences for the DDE values between the two groups.

Results: The DDE was significantly higher in group $C$ than in group $T(p=0.02)$, resulting in $10.1 \pm 3.2$ and $6.6 \pm 3$. 8 days, respectively.

Conclusions: Phytotherapic treatments for various diseases have become more common both in human and in veterinary medicine, in order to reduce the presence of antibiotic molecules in the food chain and in the environment. Administration of tannins in calves with diarrhea seemed to shorten the DDE in T by almost 4 days compared to C, suggesting an effective astringent action of chestnut tannins in the calf, as already reported in humans. The use of chestnut tannins in calves could represent an effective, low-impact treatment for neonatal diarrhea.
\end{abstract}

Keywords: Calf, Neonatal diarrhea, Chestnut tannins, Phytotherapy

\section{Background}

Calf diarrhea is a very common disease in bovine practice, and is generally caused by infectious agents [1]. The most common pathogens involved are Rotavirus, Coronavirus, Cryptosporidium parvum and Escherichia coli, especially in animals less than one month old [1,2]. Calf diarrhea causes substantial economic losses in the dairy industry, due treatment costs, a decreased growth rate in the calves, and a higher replacement rate due to culling or death [2].

In order to reduce the presence of antibiotic molecules in the food chain and in the environment, phytotherapic treatments are now commonly used both in human [3]

\footnotetext{
* Correspondence: francesca.bonelli@unipi.it

1 Dipartimento di Scienze Veterinarie, via Livornese snc, Università di Pisa, via Livornese, 56122, San Piero a Grado, Pisa, Italy

Full list of author information is available at the end of the article
}

and in veterinary medicine. Various formulations of polyphenols, such as bacteriostatic, anti-clostridial and astringent, have been tested, especially in monogastric nutrition [4-7]. Some phytotherapic options have been evaluated for gastrointestinal diseases, such as gastric ulcers and gastric lesions, in rats, piglets, horses, and calves [8-10]. Pomegranate-residue supplements have been used in neonatal calves affected by Cryptosporidium parvum, resulting in a reduction in the fecal oocyst count, as well as in intensity and duration of diarrhea [11].

Tannins are a complex group of polyphenolic compounds which are present in several plants as secondary metabolites against pathogens [12]. In ruminants, in vitro and in vivo trials have demonstrated that tannins can improve animal performance and reduce the impact of gastrointestinal parasitism, nitrogen pollution, and

(c) The Author(s). 2018 Open Access This article is distributed under the terms of the Creative Commons Attribution 4.0 International License (http://creativecommons.org/licenses/by/4.0/), which permits unrestricted use, distribution, and 
methane emission from rumen fermentation [13, 14]. Tannins may interfere with digestive processes by binding dietary protein, by modulating the activity of rumen micro-organisms, and by reducing the growth of the bacterial population [15-17].

In ruminants, tannins tend to decrease the rate of protein degradation in the rumen [18]. Tannins, in fact, inhibit the growth of proteolytic bacteria and form tannin-protein complexes in the rumen. This effect may significantly vary according to the chemical structure of the tannin and to the amount of tannin included in the diet. However, the reduction of protein degradation in the rumen increases the total amount of protein digested in the duodenum, because the tannin-protein complexes are dissociated in the abomasum, releasing protein. As a consequence, the use of moderate doses of tannins in the diet of ruminants usually improves animal performance $[18,19]$.

The astringent and anti-inflammatory effects of tannins on the gastro-enteric tract have been demonstrated in avian $[5,20]$ and swine species [9], and the effects of tannins on liver function have been evaluated in newborn calves [21].

The aim of the present study was to evaluate the effect of oral administration of chestnut tannins (Castanea sativa) in the treatment of calf neonatal diarrhea.

\section{Methods}

This in vivo blinded study was approved by the Institutional Animal Care and Use Committee (OBA, Pisa, prot. n. 33,479/2016 of 29.06.2016) and was carried out at the University of Pisa's dairy farm, where nearly 100 animals are maintained in free-stall conditions.

During the study period, the population consisted of 40 Italian Friesian calves aged between 1 and 60 days. All the calves underwent the same management condition. Briefly, immediately after birth they were weighed and then housed in a single straw-bedding pen $(2.5 \times 2 \mathrm{~m})$ that leads contact between each other. Two L of good colostrum ( $\geq 50 \mathrm{~g} / \mathrm{L}$ of Ig) from their own dam, or from the colostrum bank, were administered as soon as the calf could drink (30 min $-2 \mathrm{~h}$ ). Another $2 \mathrm{~L}$ were administered within the next $4-8 \mathrm{~h}$ in order to achieve a good passive transfer immunity [22]. All the calves received a total of $4 \mathrm{~L}$ of colostrum, twice a day, until the third day of life. Then, they received $6 \mathrm{~L}$ of whole milk at $39{ }^{\circ} \mathrm{C}$, twice a day until the third week of life.

All the feeding procedures were conducted by an expert operator and by using a nipple bucket. Even when there were cases of diarrhea, there were still no feeding restrictions or changes of feeding regime. From the third day of life, fresh and clean water were provided to each calf ad libitum. Free choice-hay was administered after the first week of life. The calves were weighed and moved into a collective pen after the third week of life.

The inclusion criteria were calves up to three weeks of life and the manifestation of diarrhea, defined as a fecal score $\geq 1$ [1]. Briefly, the fecal score represents the evaluation of feces fluidity as reported in literature: score 0 means "normal", thus firm, but not hard and the original form is distorted slightly after dropping to the floor and settling; score 1 means "soft", thus does not hold its form, but piles and spreads slightly (like soft-serve ice cream); score 2 means "runny", thus spreads readily to about $6 \mathrm{~mm}$ depth. (i.e., pancake batter); score 3 means "watery", thus liquid consistency, splatters. (i.e., orange juice) [23]. Since the first day of diarrhea (T0), the fecal score (FS) was recorded daily by the same expert operator until the complete recovery from diarrhea, at the same time, the physical examination has been done. The duration of a diarrheic episode (DDE) was defined as the period (in days) between the first diarrhea outbreak (fecal score $\geq 1$ ) and the normalizing of the FS (fecal score $=0$ ). Once the diarrhea had started, a fecal sample was collected from each calf by manual restraint. A gloved, lubricated finger was passed gently through the anus in order to massage the rectal wall and to stimulate rectal evacuation. Fresh feces were then collected in two different sterile tubes: one aliquot was immediately tested with a rapid ELISA test (test strips for detection of Rotavirus, Coronavirus, E. coli F5 and C. parvum in bovine feces, Biox Diagnostics, Belgium), while the second aliquot was stored in a refrigerated bag and evaluated within one hour for gastrointestinal parasites, according to Izzo et al. (2015) [1].

At the inclusion time, calves were randomly assigned to a control group (C) or a tannin-treated group (T), both made up of 12 calves ( 6 males and 6 females in each of the two groups). All the calves enrolled in group $\mathrm{C}$ received $\mathrm{Effydral}^{\circ}$ (Italy Zoetis Ltd.) (sodium chloride $2.34 \mathrm{~g}$, potassium chloride $1.12 \mathrm{~g}$, sodium bicarbonate $6.72 \mathrm{~g}$, citric acid anhydrous $3.84 \mathrm{~g}$, lactose monohydrate $32.44 \mathrm{~g}$, glycine $2.25 \mathrm{~g}$ ) in $2 \mathrm{~L}$ of warm water q24h. The calves assigned to group $\mathrm{T}$ received Effydral ${ }^{\circ}$ (Italy Zoetis Ltd.) in $2 \mathrm{~L}$ of warm water plus $10 \mathrm{~g}$ of chestnut tannins as extract powder $(750 \mathrm{~g} / \mathrm{kg}$ of dry matter equivalent of tannic acid; Mauro Saviola Group srl, Radicofani, Siena, Italy) q24h. The chemical composition of the powder is described in Campo et al. (2016) [24]. The powder adopted in the present study was produced in a single batch and analyzed by the manufacturer at the beginning of the study. Both solutions were administered using a graduated calves bottle in order to ensure the intake of the entire quantity. The bottle was equipped with a flexible rubber nipple $(10 \mathrm{~cm}$ of length) specific for calf feeding. 
Calves in both groups received the solutions until the normalization of the FS. Before the administration of the treatments, all the calves were daily submitted to a complete physical examination and FS evaluation until the resolution of diarrhea. Physical examination included evaluation from a distance plus hands-on examination, focusing on: physical appearance, body weight, body condition, head, mouth, eyes, ears, neck and back, thorax, abdomen, umbilicus, musculoskeletal system, perianal region, body temperature, feces, urine, and external genitalia $[25,26]$. Dehydration status was assessed with a score system [27]. Milk intake was recorded during the entire diarrheic episode.

At the conclusion of the study, the female calves were raised in the farm as rearing cows, while the male calves were sold for fattening as meat animals.

Data concerning the weight at birth and at the third week of life, the age of diarrhea onset and the T0 fecal scores (T0-FS) recorded for both groups were assessed for normal distribution by the Shapiro-Wilk normality test and then a Mann-Whitney test was applied in order to verify differences between the two groups at the inclusion time [28].

The average daily gain between birth date and third week of life was calculated for all the calves in both groups. Data concerning the average daily gain, the DDE and fecal scores recorded throughout the DDE were analyzed by a linear model including treatments and sex and their interaction as fixed factors. A Shapiro-Wilk normality test was performed to assess data distribution. A Mann-Whitney test was carried out to verify differences between the two groups regarding the average daily gain, the DDE and the fecal scoring [28]. Values with $P<0.05$ were considered statistically significant.

\section{Results}

Twenty-four out of the 40 calves, 12 males and 12 females met the inclusion criteria, and were thus included in this study. The average weight at birth was $41 \mathrm{~kg}$ (minimum value of $34.5 \mathrm{~kg}$ and maximum value of $44 \mathrm{~kg}$ ) and $37.5 \mathrm{~kg}$ (minimum value of $35 \mathrm{~kg}$ and maximum value of $48.5 \mathrm{~kg}$ ) for groups $\mathrm{C}$ and $\mathrm{T}$, respectively. The mean age at T0 was $7.9 \pm 4.8$ days for group $\mathrm{C}$, and $7.2 \pm 2.9$ days for group T. The mean T0-FS were $1.6 \pm$ 0.5 and $2.0 \pm 0.7$ for groups $C$ and $T$, respectively. No significant differences were found in terms of the weight at birth, the age of diarrhea onset, and the T0-FS between the two groups $(P>0.05)$.

There were no alterations at the physical examination, and the hydration status was normal for all calves during the entire study period. No differences between groups were found for milk intake. Thus, no pharmacological treatments or fluid therapy were needed.
Seven out of twelve (7/12) calves belonging to group C resulted positive for Cryptosporidium parvum, 2/12 for Rotavirus and Coronavirus, and 3/12 negative. Nine/12 calves belonging to group $\mathrm{T}$ were positive to Cryptosporidium parvum, 2/12 for Rotavirus and Coronavirus, and $1 / 12$ were negative to the rapid ELISA test performed. Fecal flotation did not show intestinal parasites.

The average weight at the third week of life was $53 \mathrm{~kg}$ (minimum value of $42 \mathrm{~kg}$ and maximum value of $64 \mathrm{~kg}$ ) and $46.7 \mathrm{~kg}$ (minimum value of $46 \mathrm{~kg}$ and maximum value of $52.5 \mathrm{~kg}$ ) for groups $\mathrm{C}$ and $\mathrm{T}$, respectively. The average daily gain was $0.643 \mathrm{~kg} /$ day (minimum value of $0.143 \mathrm{~kg} /$ day and maximum value of $1.024 \mathrm{~kg} /$ day), and $0.442 \mathrm{~kg} /$ day (minimum value of $0.190 \mathrm{~kg} /$ day and maximum value of $0.524 \mathrm{~kg} /$ day), for groups $\mathrm{C}$ and $\mathrm{T}$, respectively. Differences between the two groups were not significant.

The mean DDE in days was $10.3 \pm 3.5$ for group C, and $6.4 \pm 3.9$ for group $\mathrm{T}$ (Table 1). A significant difference between the two groups was found $(P=0.01)$. The mean fecal score recorded throughout the DDE for group $C$ was $1.6 \pm 0.5$, while for group $T$ the score was $1.4 \pm 0.8$, with a statistically significant difference between the two groups $(P=0.03)$. No statistically significant differences were found between male and female calves for the DDE and fecal score recorded throughout the DDE. No calves refused the tannins solution.

\section{Discussion}

Due to the high amount of antimicrobials used every year in the livestock industry and possible cross-resistance between human and animal pathogens [29, 30], for many years alternative treatments have been investigated [11].

Chestnut tannins have been proposed to modulate rumen fermentation and the degradability of food proteins in cattle [16, 17]. However, there is little information on the effects of chestnut tannins on diarrhea in neonatal calves, especially in relation to different pathogens.

The pathogen that was most isolated in our population of diarrheic calves was Cryptosporidium parvum, in line with those reported in the literature $[1,2,11]$. The mean age of diarrhea onset for all calves included was also in line with literature data $[1,2]$.

It is well known that natural plant tannins are able to control intestinal parasites in ruminants [15] and, more

Table 1 Duration of the diarrheic episode (DDE), fecal score recorded throughout the DDE of control group (C) and tannintreated group $(T)$ expressed as mean $(X) \pm$ standard deviation (SD)

\begin{tabular}{llll}
\hline & $\begin{array}{l}\text { Group C } \\
(X \pm D S)\end{array}$ & $\begin{array}{l}\text { Group T } \\
(X \pm D S)\end{array}$ & $P$ value \\
\hline DDE (days) & $10.3 \pm 3.5$ & $6.4 \pm 3.9$ & 0.0184 \\
$\begin{array}{l}\text { Fecal score recorded throughout } \\
\text { the DDE }\end{array}$ & $1.6 \pm 0.5$ & $1.4 \pm 0.8$ & 0.618 \\
\hline
\end{tabular}


in general, have antimicrobial properties [31]. The supplementation of chestnut extract in grazing heifers has been shown to lead to a significant increase in the average daily gain due to a decrease in fecal parasites infections, above all nematodes [32]. Several mechanisms of actions have been proposed for tannins, including enzyme inhibition and substrate or metal ions deprivation, and bacterial cell membrane integrity [31]. However, most studies have reported the effects of tannins (above all condensed tannins) on bacteria, fungi and nematode, whereas only few have investigated the effect of tannins on protozoa and, in particular, on Cryptosporidium parvum $[11,33]$.

The anti-protozoal activity of polyphenols has been reported for Eimeria [34-36]. A suggested mechanism is the ability of tannins to directly decrease the viability of the larval stage and disrupt egg hatching, as previously observed also for nematodes [15].

However, there have been conflicting results. Bhatta et al. (2009) found a decrease in protozoa when hydrolysable tannins from six different plant sources were applied [37]. Similar results were obtained by Tan et al. (2011), Benchaar et al. (2008) and Carulla et al. (2005) who reported that condensed tannins from Leucaena, quebracho and from Acacia mearnsii respectively, can decrease protozoal numbers [38-40]. In contrast, Vasta et al. (2010) found that quebracho tannins were able to increase protozoa in rumen liquor [41].

Differences in the concentration of tannins, plant sources, protozoal species and environment considered in such studies may explain the conflicting results obtained, because these parameters play an important role in the antiprotozoal activity of polyphenols.

To the best of our knowledge this is the first study that has investigated orally administrating tannins as a treatment for calf diarrhea. Tannins solution appeared to be pleasant for all the calves enrolled in the study and was easy to administer. The length of diarrhea was almost four days shorter in the group treated with tannins compared to the control group. Chestnut tannins seem to shorten the length of diarrhea in calves, as already reported in humans [19]. Chestnut polyphenols are ellagitannins and those from wood distillation are particularly rich in ellagic acid, such as pomegranate polyphenols [42].

Few studies have reported on the absorption and metabolism of ellagitannins in animal models. Studies of rat intestinal content demonstrated that at the caecum level ellagitannins are hydrolyzed to ellagic acid [43]. Other authors have detected free ellagic acid in human plasma after $1 \mathrm{~h}$ post ingestion of pomegranate and attributed this to the release after hydrolysis of ellagitannins according to an optimal physiological $\mathrm{pH}$ and gut microbiota activity. In addition, Cerdà et al. (2003;
2004; 2005) suggested a microbial involvement at the colon level in converting ellagic acid into urolithins, which are potent anti-inflammatory metabolites [44-46].

Although the length of diarrhea was significantly shorter in calves from group $\mathrm{T}$, no significant difference was found in terms of average daily gain between control calves and calves that received chestnut tannins. Similarly, a study based on tannins from pomegranate reported no effects of tannins on average daily gain in the first 60 days of life in dairy calves [11].

Further studies are needed in order to investigate the possible effect of hydrolysable tannins on specific etiological pathogens, in particular on Cryptosporidium parvum, as already reported for the extract of pomegranate polyphenols [11]. Also, increasing the number of animals included might clarify the effect of chestnut tannins on the average daily gain in calves affected by diarrhea.

\section{Conclusions}

Chestnut tannins might represent a low-impact treatment of neonatal diarrhea in calves. However, the effects of chestnut tannins on the onset of diarrhea and on the weight gain of calves need further investigation due to the lack of data on the metabolism of ellagitannins in ruminants.

\section{Abbreviations}

C: control group; DDE: duration of a diarrheic episode; ELISA: Enzyme-Linked Immunosorbent Assay; FS: fecal score; T: tannin-treated group

\section{Acknowledgements \\ The authors would like to thank Mauro Saviola Group srl, Radicofani, Siena, Italy for providing the chestnut tannin extract. \\ Funding \\ This research did not receive any specific grant from funding agencies in the public, commercial, or not-for-profit sectors.}

Availability of data and materials

The datasets used and analyzed are available from the corresponding author upon reasonable request.

Authors' contributions

$F B, L T$ and $M M$ designed and conducted the experiment, analyzed the resulting data and drafted the manuscript. FB, LT and GS conducted the experiment. AB and AS analyzed the resulting data and drafted the manuscript. All the authors read, revised, and approved the final manuscript.

Ethics approval and consent to participate

This study was approved by the Institutional Animal Care and Use Committee (OBA, Pisa, prot. n. 33,479/2016 of 29.06.2016) of Pisa.

\section{Consent for publication}

Not applicable.

Competing interests

The authors declare that they have no competing interests.

\section{Publisher's Note}

Springer Nature remains neutral with regard to jurisdictional claims in published maps and institutional affiliations. 


\section{Author details}

Dipartimento di Scienze Veterinarie, via Livornese snc, Università di Pisa, via Livornese, 56122, San Piero a Grado, Pisa, Italy. ${ }^{2}$ Centro di Ricerche Agro-ambientali "E. Avanzi" - Università di Pisa, via Vecchia di Marina, 6, 56122, San Piero a Grado, Pisa, Italy. ${ }^{3}$ Dipartimento di Scienze delle Produzioni Agroalimentari e Ambientali, Università di Firenze, via delle Cascine, 5, 50100 Florence, Italy.

\section{Received: 22 March 2018 Accepted: 20 July 2018}

Published online: 28 July 2018

\section{References}

1. Izzo M, Gunn AA, House JK. Neonatal diarrhea. In: Smith BP, editor. Large Animal Internal Medicine. Elsevier: United States; 2015. p. 314-35.

2. Cho Y, Yoon KJ. An overview of calf diarrhea-infectious etiology, diagnosis, and intervention. J Vet Sci. 2014;15(1):1-17.

3. Tripathi NN, Mishra AK, Tripanthi S. Antibacterial potential of plant volatile oils: a review. Proc Nat Acad Sci India Sect B. 2011;81:23-68.

4. Laudato M, Capasso R. Useful plants for animal therapy. OA Alternative Medicine. 2013:1(1):1.

5. Tosi G, Massi P, Antongiovanni M, Buccioni A, Minieri S, Marenchino L, Mele $M$. Efficacy test of a hydrolysable tannin extract against necrotic enteritis in challenged broiler chickens. Italian J An Sci. 2013;12(3):386-9.

6. Mosele Jl, Macià A, Motilva MJ. Metabolic and microbial modulation of the large intestine ecosystem by non-absorbed diet phenolic compounds: a review. Molecules. 2015;20(9):17429-68.

7. Brenes A, Viveros A, Chamorro S, Arija I. Use of polyphenol-rich grape byproducts in monogastric nutrition A review. Anim Feed Sci Technol. 2016; 211:1-17.

8. Dekanski D, Risti S, Mitrovi DM. Antioxidant effect of dry olive (Olea europaea L.) leaf extract on ethanol-induced gastric lesions in rats. Med J Nutr Metab. 2009;2(3):205-11.

9. Ayrle H, Mevissen M, Kaske M, Nathues H, Gruetzner N, Melzig M, Walkenhorst M. Medicinal plants - prophylactic and therapeutic options for gastrointestinal and respiratory diseases in calves and piglets? A systematic review. BMC Vet Res. 2016;12:89.

10. Bonelli F, Busechian S, Meucci V, Caporrino G, Briganti A, Rueca F, Zappulla F, Ferini $E$, Ghiandai L, Sgorbini M. pHyloGASTRO in the treatment of equine gastric ulcer lesions. J Equine Vet Sci. 2016;46:69-72.

11. Weyl-Feinstein S, Markovics A, Eitam H, Orlov A, Yishay M, Agmon R, Miron J, Izhaki I, Shabtay A. Effect of pomegrate-residue supplement on Cryptosporidium parvum oocystis shedding in neonatal calves. J Dairy Sci. 2014;97:5800-5.

12. Frutos P, Hervas G, Giraldez FJ, Mantecon AR. Review. Tannins and ruminant nutrition. Span J Agric Res. 2004;2(2):191-202.

13. Animut G, Puchala R, Goetsch A, Patra A, Sahlu T, Varel V, Wells J. Methane emission by goats consuming different sources of condensed tannins. Anim Feed Sci Technol. 2008;144:228-41.

14. Getachew G, Pittroff W, Putnam DH, Dandekar A, Goyal S, Depeters EJ. The influence of addition of gallic acid, tannic acid, or quebracho tannins to alfalfa hay on in vitro rumen fermentation and microbial protein synthesis. Anim Feed Sci Technol. 2008;140:444-61.

15. Min BR, Hart SP. Tannins for suppression of internal parasites. J Anim Sci. 2003;81(E. Suppl. 2):E102-9.

16. Buccioni A, Pauselli M, Viti C, Minieri S, Pallara G, Roscini V, Rapaccini S, Marinucci MT, Lupi P, Conte G, Mele M. Milk fatty acid composition, rumen microbial population, and animal performances in response to diets rich in linoleic acid supplemented with chestnut or quebracho tannins in dairy ewes. J Dairy Sci. 2015:98(2):1145-56.

17. Buccioni A, Serra A, Minieri S, Mannelli F, Cappucci A, Benvenuti D, Rapaccini S, Conte G, Mele M. Milk production, composition, and milk fatty acid profile from grazing sheep fed diets supplemented with chestnut tannin extract and extruded linseed. Small Rum Res. 2015;130:200-7.

18. Patra AK, Saxena J. Exploitation of dietary tannins to improve rumen metabolism and ruminant nutrition. J Sci Food Agric. 2011;91(1):24-37.

19. Ashok PK, Upadhyaya K. Tannins are stringent. J Pharmacogn Phytochem. 2012;1(3):45-50

20. Graziani $\mathrm{R}$, Tosi G. In vitro anti-microbial activity of SILVA FEED ENC ${ }^{\circledast} \operatorname{tannin}$ on bacterial strains of poultry origin. Worlds Poult Sci J. 2006;62:384-5.

21. Wieland M, Weber BK, Hafner-Marx A, Sauter-Louis C, Bauer J, KnubbenSchweizer G, Metzner M. A controlled trial on the effect of feeding dietary chestnut extract and glycerol monolaurate on liver function in newborn calves. J Anim Physiol Anim Nutri. 2015:99:190-200.

22. Godden S. Colostrum management for dairy calves. Vet Clin North Am Food Anim Pract. 2008:24(1):19-39.

23. Larson LL, Owen FG, Albright JL, Appleman RD, Lamb RC, Muller LD. Guidelines toward more uniformity in measuring and reporting calf experimental data. J Dairy Sci. 1977;60(6):989-91.

24. Campo M, Pinelli $P$, Romani A. Hydrolyzable tannins from sweet chestnut fractions obtained by a sustainable and eco-friendly industrial process. Nat Prod Commun. 2016;11(3):409-15.

25. Bonelli F, Castagnetti C, lacono E, Corazza M, Sgorbini M. Evaluation of some physical, haemathological and clinical chemistry parameters in healthy newborn Italian Holstein calves. Am J Anim Vet Sci. 2015; 10(4):230-4.

26. House JK, Gunn AA, Chuck G, McGuirk SM. Initial management and clinical investigation of neonatal disease. In: Smith BP, editor. Large Animal Internal Medicine. Elsevier: United States; 2015. p. 294-301.

27. Constable PD, Gohar HM, Morin DE, Thurmon JC. Use of hypertonic salinedextran solution to resuscitate hypovolemic calves with diarrhea. Am J Vet Res. 1996;57(1):97-104

28. SAS. User's guide: statistics, version 8.0 edition. SAS Inst. Inc., Cary, NC, USA. 1999.

29. World Health Organization (WHO): Second joint FAO/OIE/WHO expert workshop on non-human antimicrobial usage and antimicrobial resistance: Management options. Oslo, WHO, 2004.

30. Marshall BM, Levy SB. Food animals and antimicrobials: impacts on human health. Clin Microbiol Rev. 2011:24:718-33.

31. Scalbert A. Antimicrobial properties of tannins. Phytochemistry. 1991;30(12): 3875-83.

32. Min BR, Pinchak WE, Hernandez K, Hernandez C, Hume ME, Valencia E, Fulford JD. Effects of plant tannin supplementation on animal responses and in vivo ruminal bacterial populations associated with bloat in heifers grazing wheat forage. The Professional Animal Scientist. 2012;28:464-72.

33. Al-Mathal EM, Alsalem AM. Pomegranate (Punica granatum) peel is effective in a murine model of experimental Cryptosporidium parvum. Exp Parasitol. 2012;131:350-7.

34. Landau S, Azaizeh H, Mukladaa H, Glasserc T, Ungara ED, Barama H, Abbasd N. Markovicsd A. Anthelmintic activity of Pistacia lentiscus foliage in two middle eastern breeds of goats differing in their propensity to consume tannin-rich browse. Vet Parasitol. 2010;173:280-6.

35. Markovics A, Cohen I, Muklada H, Glasser TA, Dvash L, Ungar ED, Azaizeh H, Landau SY. Consumption of Pistacia lentiscus foliage alleviates coccidiosis in young goats. Vet Parasitol. 2012;25:165-9.

36. Burke JM, Miller JE, Terrill TH, Orlik ST, Acharya M, Garza JJ, Mosjidis JA. Sericea lespdeza as an aid in the control of Emeria spp. in lambs. Vet Parasitol. 2013;193:39-46.

37. Bhatta R, Uyeno Y, Tajima K, Takenaka A, Yabumoto Y, Nonaka I, Enishi O, Kurihara M. Difference in the nature of tannins on in vitro ruminal methane and volatile fatty acid production and on methanogenic archaea and protozoal populations. J Dairy Sci. 2009;11:5512-22.

38. Carulla JE, Kreuzer M, Machmuller B, Hes HD. Supplementation of Acacia mearnsii tannins decreases methanogenesis and urinary nitrogen in foragefed sheep. Austral J Agric Res. 2005:56:961-70.

39. Benchaar C, McAllister TA, Chouinard PY. Digestion, ruminal fermentation, ciliate protozoal populations, and milk production from dairy cows fed Cinnamaldehyde, Quebracho condensed tannin, or Yucca schidigera Saponin extracts. J Dairy Sci. 2008;12:4765-77.

40. Tana HY, Sieoa CC, Abdullaha N, Lianga JB, Huanga XD, Ho YW. Effects of condensed tannins from Leucaena on methane production, rumen fermentation and populations of methanogens and protozoa in vitro. Anim Feed Sci Technol. 2011;169:185-93.

41. Vasta V, Yanez-Ruiz DR, Mele M, Serra A, Luciano G, Lanza M, Biondi L, Priolo A. Bacterial and protozoal communities and fatty acid profile in the rumen of sheep fed a diet containing added tannins. Appl Envir Microbiol. 2010; 76(8):2549-55

42. De Vasconcelos M, Bennett RN, Rosa EAS, Ferreira-Cardoso JV. Composition of european chestnut (Castanea sativa Mill.) and association with health effects:fresh and processed products. J Sci Food Agric. 2010:90:1559-78.

43. Daniel EM, Ratnayake S, Kinstle T, Stoner GD. The effects of pH and rat intestinal contents on the liberation of ellagic acid from purified and crude ellagitannins. J Nat Prod. 1991;54:946-52. 
44. Cerdá B, Llorach R, Cerón JJ, Espín JC, Tomás-Barberán FA. Evaluation of the bioavailability and metabolism in the rat of punicalagin and antioxidant polyphenol from pomegranate juice. Eur J Nutr. 2003;42:18-28.

45. Cerdá B, Espín JC, Parra S, Martínez P. Tomás-Barberán FA. The potent in vitro antioxidant ellagitannins from pomegranate juice are metabolized into bioavailable but poor antioxidant hydroxy-6H-dibenzopyran-6-one derivatives by the colonic microflora in healthy humans. Eur J Nutr. 2004;43:205-20.

46. Cerda B, Tomas-Barberan FA, Espin JC. Metabolism of antioxidant and chemopreventive ellagitannins from strawberries, raspberries, walnuts, and oak-aged wine in humans: identification of biomarkers and individual variability. J Agric Food Chem. 2005;53:227-35.

Ready to submit your research? Choose BMC and benefit from:

- fast, convenient online submission

- thorough peer review by experienced researchers in your field

- rapid publication on acceptance

- support for research data, including large and complex data types

- gold Open Access which fosters wider collaboration and increased citations

- maximum visibility for your research: over $100 \mathrm{M}$ website views per year

At BMC, research is always in progress.

Learn more biomedcentral.com/submissions 